\title{
Correlation of Fetal Growth Between Last Menstrual Period and third Trimester Ultrasound Pregnancy on Ethnic Minangkabau
}

\author{
Yusrawati Yusrawati ${ }^{1 *}$, Joserizal Serudji ${ }^{1}$, Bobby Indra Utama ${ }^{2}$, Puspita Sari $^{2}$ \\ ${ }^{1}$ Department of Obstetrics and Gynecology, Fetomaternal Division, Medical Faculty, Andalas University, Padang, West Sumatera, \\ Indonesia; ${ }^{2}$ Department of Obstetrics and Gynecology, Medical Faculty, Andalas University, Padang, West Sumatera, Indonesia
}

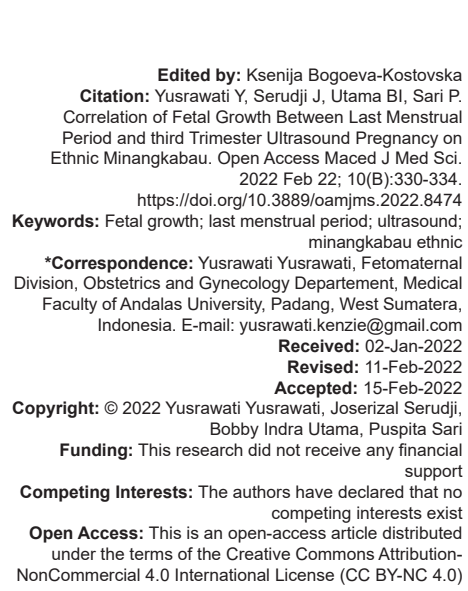

\section{Introduction}

Fetal growth is a vital thing that determines the quality of life at birth and is the most important factor for perinatal morbidity and mortality [1]. Maternal race and ethnicity are important parameters that distinguish fetal size and birth weight [2], [3]. In one study, there was a difference in size of infants of European descent, on average $225.5 \mathrm{~g}$ heavier than infants of Chinese descent and $254.6 \mathrm{~g}$ heavier than infants of South Asian descent [2]. Early manifestations of this phenotype indicate that it caused by genetics and/or determined through maternal physiological exposure, not as a result of behavior or diet in childhood or later in life [2], [4], [5].

Since ultrasonography (USG) technology was discovered more than 40 years ago, fetal biometry with ultrasound measurements has become the prima donna and is considered an accurate method for estimating the baby's birth weight [6], [7]. As science advances and there are more and more approaches to measurement fetuses to determine the estimated birth weight of babies, including the formulas of Jeanty, Aoki, Campbell, Shepard, Hadlock, and other research approaches that are still being developed [8]. Formulas and growth charts were introduced by Hadlock more than 20 years ago. Among them, Pressman et al. stated that the Hadlock formula (biparietal diameter [BPD], head circumference [HC], abdominal circumference [AC], and femur length [FL]) in determining fetal weight for 138 pregnant women was more accurate [9], [10], [11], [12].

Then, came the multicenter longitudinal studies of the Intergrowth-21 (IN-21) project that presented fetal biometric standards for various populations. The National Institute of Child Health and Human Development (NICHD) together with the WHO study, all of these studies form the main basis for a new discussion of standard parameters of fetal growth [10]. Because the multinational studies currently available represent a very limited selection from a varied world population, then it is possible to graph a specific population growth as a solution (e.g., population adjusted based on high altitude or regional extreme conditions, economic 
conditions, technology availability, cultural differences, etc.) [5], [12], [13].

Indonesia does not yet have a reference standard for fetal weight percentiles. As a developing country, with a population of more than 200 million people, ethnic, and cultural diversity, there should be a suitable reference standard for us to use, so there is a mistake in labeling or managing pregnancies with normal fetuses or fetuses that need further attention.

Therefore, the authors would like to conduct research to obtain references that are in accordance with fetal growth for the Indonesian people, especially the Minangkabau ethnicity. In addition, the authors feel the need to explain the correlation between several parameters in ultrasound examination (BPD, AC, HC, $\mathrm{HL}$, and $\mathrm{FL}$ ) with gestational age according to the last menstrual period (LMP) so that this study is expected to provide results in the form of more parameters and accurate in determining fetal growth estimates.

\section{Methods}

This research is an analytical research using a cross-sectional approach that determines fetal growth biometry in the Minangkabau ethnic group. The study was conducted in December 2020 at Fetomaternal clinic Hospital M. Djamil Padang and Network Hospital in the Department of Obstetrics and Gynecology Faculty of Medicine Andalas University. The selected sample was pregnant women who came to check their pregnancy at the Fetomaternal Clinic at M. Djamil Hospital Padang and a network hospital who meet the inclusion and exclusion criteria. The inclusion criteria are willing to be a research subject, single and intrauterine pregnancy, gestational age 28-40 weeks, and normal body mass index (BMI 18.5-24.9). The exclusion criteria are fetal anomaly, pregnancy with a history of myoma or cyst disease, hypertension, diabetes mellitus, kidney disease, heart disease, autoimmune (SLE); and pregnancy with a history of smoking and alcohol consumption, drugs, long-term use of drugs such as steroids, anti-hypertensives, and insulin. Hence, the sample collected is 520 samples for each gestational age from weeks 28 to 40 .

Sampling was done by consecutive sampling to all pregnant women who came to the Fetomaternal Clinic at RSUP DR. M. Djamil Padang who met the inclusion criteria and there were no exclusion criteria to meet the number of research subjects. The dependent variable is fetal biometry such as (BPD, AC, $\mathrm{HC}, \mathrm{HL}$, and $\mathrm{FL})$. All of the dependent variables were presented in millimeters. The independent variable was gestational age (GA) presented in weeks.
Univariate analysis was used to determine the description of the dependent and independent variables of the study. The results of this analysis aim to describe the frequency distribution in tabular form. Bivariate analysis using Pearson correlation test because the data distribution was normally distributed. $\mathrm{P}<0.05$ has a significant correlation. Multivariate analysis using linear regression used to measuring valid variables with $p<0.05$. All data were analyzed using a computer program and SPSS.

This research involves humans as research subjects and the materials used are fetus. The ethical implications of this study follow the provisions of the Declaration of Helsinki and have passed the ethical test number 333/KEPK/2021. All medical matters relating to this research are confidential. Research subjects have the right to refuse to participate in the study if they do not agree. All research costs and other costs incurred as a result of this research are borne by the researcher.

\section{Results}

Five hundred and twenty pregnant women came to check at third trimester (28-40 weeks by the US), the characteristic distribution of subject is shown in Table 1 below.

Table 1: Characteristic of the Study of Subject

\begin{tabular}{ll}
\hline Characteristic & $\mathrm{X} \pm \mathrm{SD}$ \\
\hline Age (year) & $28.49 \pm 4.5$ \\
$<20$ & 11 \\
$21-39$ & 501 \\
$\geq 40$ & 8 \\
Parity & \\
0 & $175(33.7)$ \\
1 & $203(46.7)$ \\
2 or more & $102(19.6)$ \\
Education & \\
No college & $1(0.2)$ \\
JHS* & $12(2.3)$ \\
SHS* & $431(82.9)$ \\
College Graduate & $76(14.6)$ \\
Job Status & \\
Civil servant & $65(12.5)$ \\
Private employee & $47(9.0)$ \\
Entrepreneur & $111(21.3)$ \\
No work & $297(57.1)$ \\
\hline
\end{tabular}

The fetal growth between LMP and third trimester ultrasound pregnancy in ethnic Minangkabau is shown from Table 2 .

From Table 1, we can see that the mean age of subject is in reproductive age. The most of subjects have zero and one parity. The level of maternal education is mostly at the SHS level, for the job status of the research subjects, most of them do not work, namely, only as housewives.

From Table 2, we can see the mean biometrics GA according to the LMP. The result of fetal biometrics measurements by Ultrasound in each subject for 
Table 2:Mean fetal biometry in third trimester according to gestasional age according to the LMP

\begin{tabular}{|c|c|c|c|c|c|c|c|c|c|c|c|c|c|}
\hline \multirow[t]{2}{*}{ Mean (SD) } & \multicolumn{13}{|c|}{ Gestational age in third Pregnancy $(n=40)$} \\
\hline & 28 & 29 & 30 & 31 & 32 & 33 & 34 & 35 & 36 & 37 & 38 & 39 & 40 \\
\hline BPD (cm) & $\begin{array}{l}7.37 \\
(0.468)\end{array}$ & $\begin{array}{l}7.48 \\
(0.522)\end{array}$ & $\begin{array}{l}7.62 \\
(0.318)\end{array}$ & $\begin{array}{l}7.83 \\
(0.365)\end{array}$ & $\begin{array}{l}8.19 \\
(0.355)\end{array}$ & $\begin{array}{l}8.38 \\
(0.346)\end{array}$ & $\begin{array}{l}8.41 \\
(0.889)\end{array}$ & $\begin{array}{l}8.74 \\
(0.405)\end{array}$ & $\begin{array}{l}8.89 \\
(0.411)\end{array}$ & $\begin{array}{l}9.11 \\
(0.284)\end{array}$ & $\begin{array}{l}9.22 \\
(0.266)\end{array}$ & $\begin{array}{l}9.34 \\
(0.384)\end{array}$ & $\begin{array}{l}9.54 \\
(0.437)\end{array}$ \\
\hline $\mathrm{HC}(\mathrm{cm})$ & $\begin{array}{l}26.29 \\
(1.773)\end{array}$ & $\begin{array}{l}26.98 \\
(1.998)\end{array}$ & $\begin{array}{l}27.66 \\
(1.303)\end{array}$ & $\begin{array}{l}28.18 \\
(1.187)\end{array}$ & $\begin{array}{l}29.29 \\
1.516)\end{array}$ & $\begin{array}{l}30.23 \\
(2.862)\end{array}$ & $\begin{array}{l}30.61 \\
(1.453)\end{array}$ & $\begin{array}{l}31.34 \\
(3.729)\end{array}$ & $\begin{array}{l}31.35 \\
(3.582)\end{array}$ & $\begin{array}{l}31.59 \\
(1.023)\end{array}$ & $\begin{array}{l}32.38 \\
(1.302)\end{array}$ & $\begin{array}{l}32.59 \\
(1.435)\end{array}$ & $\begin{array}{l}33.52 \\
(3.112)\end{array}$ \\
\hline $\mathrm{AC}(\mathrm{cm})$ & $\begin{array}{l}24.01 \\
(2.65)\end{array}$ & $\begin{array}{l}24.69 \\
(3.766)\end{array}$ & $\begin{array}{l}26.03 \\
(1.995)\end{array}$ & $\begin{array}{l}26.93 \\
(2.25)\end{array}$ & $\begin{array}{l}27.76 \\
(2.26)\end{array}$ & $\begin{array}{l}28.45 \\
(2.251)\end{array}$ & $\begin{array}{l}29.25 \\
(3.339)\end{array}$ & $\begin{array}{l}30.55 \\
(3.391)\end{array}$ & $\begin{array}{l}31.59 \\
(2.33)\end{array}$ & $\begin{array}{l}32.31 \\
(1.637)\end{array}$ & $\begin{array}{l}32.58 \\
(3.818)\end{array}$ & $\begin{array}{l}32.87 \\
(1.933)\end{array}$ & $\begin{array}{l}33.49 \\
(4.035)\end{array}$ \\
\hline $\mathrm{FL}(\mathrm{cm})$ & $\begin{array}{l}5.29 \\
(0.457)\end{array}$ & $\begin{array}{l}5.51 \\
(0.555)\end{array}$ & $\begin{array}{l}5.95 \\
(0.737)\end{array}$ & $\begin{array}{l}6.18 \\
(0.456)\end{array}$ & $\begin{array}{l}6.3 \\
(0.34)\end{array}$ & $\begin{array}{l}6.75 \\
(0.406)\end{array}$ & $\begin{array}{l}6.84 \\
(0.953)\end{array}$ & $\begin{array}{l}6.95 \\
(0.291)\end{array}$ & $\begin{array}{l}7.14 \\
(0.426)\end{array}$ & $\begin{array}{l}7.31 \\
(0.295)\end{array}$ & $\begin{array}{l}7.61 \\
(0.203)\end{array}$ & $\begin{array}{l}7.85 \\
(0.444)\end{array}$ & $\begin{array}{l}7.95 \\
(2.488)\end{array}$ \\
\hline $\mathrm{HL}(\mathrm{cm})$ & $\begin{array}{l}4.86 \\
(0.475)\end{array}$ & $\begin{array}{l}5.28 \\
(2.5485)\end{array}$ & $\begin{array}{l}5.32 \\
(6.039)\end{array}$ & $\begin{array}{l}5.48 \\
(0.445)\end{array}$ & $\begin{array}{l}5.63 \\
(0.369)\end{array}$ & $\begin{array}{l}5.71 \\
(0.433)\end{array}$ & $\begin{array}{l}5.86 \\
(0.363)\end{array}$ & $\begin{array}{l}5.93 \\
(0.589)\end{array}$ & $\begin{array}{l}6.11 \\
(0.274)\end{array}$ & $\begin{array}{l}6.22 \\
(0.348)\end{array}$ & $\begin{array}{l}6.27 \\
(0.389)\end{array}$ & $\begin{array}{l}6.21 \\
(0.513)\end{array}$ & $\begin{array}{l}6.46 \\
(0.477)\end{array}$ \\
\hline
\end{tabular}

the third trimester of pregnancy to LMP is shown by increasing variability with gestational age for all the five variables.

The correlation of fetal growth between LMP and third trimester ultrasound pregnancy on ethnic Minangkabau is shown in Table 3.

Table 3: Correlation between of each variable BPD, HC, AC, FL, and HL to LMP

\begin{tabular}{llll}
\hline $\begin{array}{l}\text { Dependent variable } \\
\text { (weeks) }\end{array}$ & $\begin{array}{l}\text { Independent variables } \\
(\mathrm{cm})\end{array}$ & $\begin{array}{l}\text { Pearson correlation } \\
\mathrm{r}\end{array}$ & $\mathrm{p}$ value \\
\hline LMP & BPD & 0.779 & 0.000 \\
LMP & HC & 0.699 & 0.000 \\
LMP & AC & 0.799 & 0.000 \\
LMP & FL & 0.212 & 0.000 \\
LMP & HL & 0.162 & 0.000 \\
\hline
\end{tabular}

From Table 3, it can be seen that the strongest correlation is $\mathrm{AC}, \mathrm{BPD}$, and $\mathrm{HC}$ followed by $\mathrm{FL}$ and the lowest is $\mathrm{HL}$, with a very significant level of significance from all variables.

According to the LMP, a linear regression T-test is carried out which is shown in Table 4.

\section{Table 4: t-test}

\begin{tabular}{lllll}
\hline $\begin{array}{l}\text { Dependent } \\
\text { Variable (weeks) }\end{array}$ & $\begin{array}{l}\text { Independent } \\
\text { Variables }(\mathrm{cm})\end{array}$ & $\mathrm{T}_{\text {value }}$ & $\mathrm{t}_{\text {table }}$ & $\mathrm{p}$ value \\
\hline LMP & $\mathrm{BPD}$ & 8.721 & 2.571 & 0.000 \\
LMP & $\mathrm{HC}$ & 2.523 & 2.571 & 0.012 \\
LMP & $\mathrm{AC}$ & 10.920 & 2.571 & 0.000 \\
LMP & $\mathrm{FL}$ & $1.872-1.062$ & 2.571 & 0.062 \\
LMP & $\mathrm{HL}$ & & 2.571 & 0.289 \\
\hline
\end{tabular}

Based on Table 4, we can see that the most appropriate variables for gestational age by LMP are BPD and AC with a value of $p<0.01$ followed by $H C$ and $\mathrm{FL}$. $\mathrm{HL}$ is the most unsuitable variable.

To see the role of fetal biometric variables simultaneously on gestational age according to the LMP, we carried out a multiple linear regression F-test which is shown in Table 5.

\section{Table 5: F-test} \begin{tabular}{lllll}
\hline Dependent variable (weeks) & Independent variables $(\mathrm{cm})$ & $\mathrm{F}_{\text {value }}$ & $\mathrm{F}_{\text {table }}$ & R square \\
\hline LMP & BPD. HC. AC. FL. HL & 239.433 & 1.90 & 0.846
\end{tabular}

From Table 5, it can be seen that the measurement of all biometric variables of fetal growth simultaneously on gestational age according to the LMP seems to be influential, as shown by $F$ value $>F$ table with $\mathrm{R}$ square $84.6 \%$.

\section{Discussion}

In this study, there were 520 pregnant women who came to check at third trimester that included in the study. The characteristics of the research subjects are that the average age of pregnant women ranging from 21 to 39 years with the average is $28.49 \pm 4.5$ years, zero and one parity percentage is $46.7 \%$, and the average level of education at senior high school percentage is $82.9 \%$, and there were 123 working pregnant which is equivalent to $42.5 \%$ and is shown in Table 1 . All of these factors are part of the significant determinants for fetal growth.

Along with this result, based on the study that published by Troe et al., that had examine data of 6044 pregnant women residing in Netherlands (Dutch and Non Dutch ethnics), shows that the average age of Dutch pregnant women in Netherlands is $31.2 \pm$ 4.5 years, while the non-Dutch women's average age is $26.1 \pm 5.4$ years, Dutch women's parity percentage is $58.6 \%$ and non-Dutch's is $38.0 \%$. The higher education of Dutch women's percentage is $56.7 \%$, non-Dutch women's is $12.2 \%$ [14]. These results confirm significant contribution of educational level, maternal age, and parity status even though it has smaller contribution than maternal and parental height and lower gestational age [1], [2], [14], [15], [16]. From this, we can conclude that nulliparity may not pose a risk to fetal growth.

While the other hand, the other study that performed by Chiara di Gravio et al., about "The Mumbai Maternal Nutrition Project (MMNP)" showed a high incidence of maternal age at a very young age ( $\leq 19$ years) and advanced age ( $\geq 35$ years), which is the maternal age during pregnancy has been linked to adverse fetal and birth outcomes. Young maternal age is associated with an increased risk of fetal growth restriction, preterm delivery, low birth weight (LBW), small for gestational age (SGA), and neonatal mortality. 2-5 maternal nulliparity is a risk factor for suboptimal maternal hemodynamic adaptations during pregnancy, which may adversely affect fetal nutrient supply. Children of nulliparous mothers have slower fetal growth rates from third trimester onward and accelerated infant growth rates [15].

Mean fetal biometrics in the third trimester compared with gestational age; according to the LMP 
in the Minangkabau ethnic at 28 weeks of gestation, the variable BPD is $7.37 \mathrm{~cm}$ and at 40 weeks is $9.54 \mathrm{~cm}$. Variable of $\mathrm{AC}$ at 28 weeks of gestation was $24.01 \mathrm{~cm}$ and at 40 weeks is $33.49 \mathrm{~cm}$. The result of this study illustrates that there is an increase in variability according to the gestational age in all variables.

In the study of Al Marri et al., in the Kingdom of Saudi Arabia, the means BPD values for each week of GA show growth of BPD values at every level of its week; even though the differences with the BPD values of USA, Norway, Australia, Zimbabwe, India, China, and Malaysia are not really significant. Thus, these new BPD values made by Al marri are highly recommended to be used by the medical practitioner as the reference range of fetal biometry for Saudi Arabia population, in regards to provide a better healthcare and well-being of the maternal and fetuses [17], [18], [19], [20]. In accordance with Al Marri's study in determining the new BPD variable in Saudi Arabia, this study is also an attempt to create a new standard and the value of the new BPD variable that can be used by practitioners in Indonesia especially in the Minangkabaru Ethnic, in determining fetal growth.

According to Jhonsons et al., in his study of "Longitudinal reference charts for growth of the fetal head, abdomen, and femur", explained that the length of BPD at 28 weeks is $7.5 \mathrm{~cm}$ and at 40 weeks is $11.3 \mathrm{~cm}$, variable of AC at 28 weeks is $24.0 \mathrm{~cm}$ and 40 weeks is $36.0 \mathrm{~cm}$. Some literature it is stated that there are important differences in body weight, length, and $\mathrm{HC}$ reported in infants according to the ethnicity [18]. This means that there are some differences in the biometric measurements between foreigners and Indonesians also. Which is also tends to conclude that the fetal size of foreigners tends to be larger than Indonesian's, therefore, we need more specific data for the size of Indonesians, especially for the Minangkabau ethnic.

The results of this study indicate a correlation of fetal growth between LMP and the variables of BPD, $\mathrm{HC}, \mathrm{AC}, \mathrm{FL}$, and $\mathrm{HL}$ in the Minangkabau ethnic which is shown in Table 3. There is the strongest correlation between LMP and AC, $r=0.799$ and the weakest correlation between LMP and HL, $r=0.162$. Based on Table 3 , all variables are very significant as evidenced by $(p<0.05)$.

In the study of Jacquemyn et al., toward Belgians and Non-Belgian (from Turkey and Marocco), Fetal biometry, shows that there is no significant difference between these three different ethnic groups that could be demonstrated for the BPD $(P=0.39)$. Differences do exist for the $\mathrm{HC}$, the $A C$, the $F L$, and the estimated fetal weight. The use of adapted charts of fetal size for pregnant women of Turkish or Moroccan origin should be considered [1], [6], [18]. However, the BPD of Indonesians is very influential on LMP according to the study; we have done, due to differences of body genes from European and Mediterranean ethnics when compared to Indonesians. Therefore, $\mathrm{HC}, \mathrm{AC}$, and FL of European and Mediterranean (Turkish and Moroccan) people have more effect on gestational age according to the LMP, especially the FL variable which has the strongest effect compared to other variables; this is due to their height genes which far exceed Indonesian height.

Based on Tables 4 and 5 , it can be seen that the most appropriate variables for gestational age by LMP are BPD and AC with a value of $p<0.01$ followed by $\mathrm{HC}$ and $\mathrm{FL}$. $\mathrm{HL}$ is the most unsuitable variable, and then there is a significant effect between the fetal biometric variable (BPD, $\mathrm{HC}, \mathrm{AC}, \mathrm{FL}$, and $\mathrm{HL}$ ) on LMP together while $F$ value $>F$ table. The effects will give more significant result of $84.6 \%$.

BPD, HC, AC, FL, and actual birth weights (ABW) were also taken in Sudan by Caroline Edward Ayad in her study of "Assessment of Used Formulae for Sonographic Estimation of Fetal Weight in Sudanese Population." This statistical analysis showed significant results at $p \leq 0.005$ [12], [19], [20]. In other words, the study conducted by Caroline in Sudan is concrete evidence of a correlation between fetal biometry and LMP on fetal growth, as we have also done this study on pregnancy in Indonesia especially Minangkabau ethnic.

From Hadlock study, the variability in predicting menstrual age from AC measurements is broader than that observed with the fetal BPD; nonetheless, this measurement can be useful as an adjunct in predicting menstrual age in cases, in which, the BPD is technically inadequate or impossible to obtain due to unusual positioning. for growth parameters, including BPD, $\mathrm{HC}$, $A C$, and FL. Pre-eliminary experience (unpublished data) suggests that this combination of parameters is more accurate in predicting menstrual age than any single parameter, particularly in third trimester of pregnancy [12], [20].

At last, all the journals that are included in this study state that there is significant connection between each biometry variables (BPD, $\mathrm{HC}, \mathrm{AC}, \mathrm{FL}$, and $\mathrm{HL}$ ) on gestational age according to the LMP, whether the relationship is described one by one as we found in several journals, or putting it together entirely to find a significant relationship between all these variables with gestational age according to the LMP.

In addition, this study shows that ethnic differences can affect fetal growth, as other external factors can also be associated such as maternal weight, height, age, and parity. We thus considered the importance of developing fetal growth curves that account for different maternal and fetal characteristics of different ethnicities.

The results of this study are ultimately expected to be standard third trimester intrauterine fetal growth chart in Minangkabau ethnic. 


\section{Conclusion}

There is a significant correlation fetal growth between LMP and third trimester ultrasound pregnancy with variable $\mathrm{BPD}, \mathrm{HC}, \mathrm{AC}, \mathrm{FL}$, and $\mathrm{HL}$ on Minangkabau ethnic.

\section{References}

1. Cunningham FG, Lenovo KJ, Bloom SL, Dashe JS, Hoffman BL, Casey BM, et al. Williams Obstetrics. $25^{\text {th }}$ ed. New York: McGraw-Hill Education; 2018. p. 1870-87.

2. ACOG. Nutrition during Pregnancy. United States: American College of Obstetricians and Gynecologists; 2018.

3. Kiserud T, Piaggio G, Carroli G, Widmer M, Carvalho J, Jensen LN, et al. The World Health Organization fetal growth charts: A multinational longitudinal study of ultrasound biometric measurements and estimated fetal weight. PLoS Med. 2017;14(1):e1002220. http://doi.org/10.1371/journal. pmed.1002220

PMid:28118360

4. Mikolajczyk RT, Zhang J, Betran AP, Souza JP, Mori R, Gülmezoglu AM, et al. A global reference for fetal-weight and birthweight percentiles. Lancet. 2011;377(9780):1855-61. http:// doi.org/10.1016/S0140-6736(11)60364-4

PMid:21621717

5. Sletner L, Jenum AK, Yajnik CS, Mørkrid K, Nakstad B, Rognerud-Jensen $\mathrm{OH}$, et al. Fetal growth trajectories in pregnancies of European and South Asian mothers with and without gestational diabetes, a population-based cohort study. PLoS One. 2017;12(3):e0172946. http://doi.org/10.1371/ journal.pone. 0172946 PMid:28253366

6. Melamed N, Ryan G, Windrim R, Toi A, Kingdom J. Choise of formula and accuracy of fetal weight estimation in small for gestional-age fetuses. J Ultrasound Med. 2016;35(1):71-82. http://doi.org/10.7863/ultra.15.02058

PMid:26635253

7. Depkes RI. Penyakit Penyebab Kematian Bayi Bayi Lahir (Neonatal) dan Sistem Pelayanan Kesehatan Yang Berkaitan Di Indonesia; 2017. Available from: https://www.digilib.litbang. depkes.goid.jakarta [Last accessed on 2021 Jun 10].

8. Benson CB, Doubilet PM. Fetal biometry and growth. In: Norton PW, Callen ME. Callen's Ultrasonography in Obstetrics and Gynecology. $6^{\text {th }}$ ed. Philadelphia, PA: Elsevier; 2017. p. 118-28.

9. MacGregor SN, Sabbagha RE. Assessment of gestational age by ultrasound. In: GLOWM: The Global Library of Women's Medicine; 2008. http://doi.org/10.3843/GLOWM.10206
10. Kiserud T, Benachi A, Hecher K, Perz RG, Carvalho J, Piagio G, et al. The World Health Organization fetal growth charts: Concept, findings, interpretation, and application. Am J Obstet Gynecol. 2018;218(2S):S619-29. http://doi.org/10.1016/j.ajog.2017.12.010 PMid:29422204

11. Mawengkang M. Estimated birth weight based on measurement of biparietal diameter, head circumference, femur length and fetal abdominal circumference. Obst Ginecol Bull. 2013;21(1):16-9.

12. Hadlock FP, Harris RB, Sharman RS, Peter RL, Park SK. Estimation of fetal weight with the use of head, body, and femur measurement-a prospectivee study. Am J Obstet Gynecol. 1985;151(3):333-7. http://doi. org/10.1016/0002-9378(85)90298-4 PMid:3881966

13. Beckmann CR, Ling FW, Herbert WN, Laube DW, Smith RP. Fetal growth abnormalities: Intrauterine growth restriction and macrosomia. In: Horowitz L, Ferran A, editors. Beckmann and Ling's Obstetrics and Gynecology. $8^{\text {th }}$ ed. Philadelphia, PA: Lippincott Williams \& Wilkins; 2019. p. 350-61.

14. TroeEJ, RaatH, JaddoeVW, HofmanA, Looman CW, MollHA, etal. Explaining Differences in birth-weightbetween ethnicpopulations. The Generation R study. BJOG. 2007;114(12):1557-65. http:// doi.org/10.1111/j.1471-0528.2007.01508.x PMid:17903227

15. Lawande A, di Gravio C, Potdar RD, Sahariah SA, Gandhi M, Chopra $\mathrm{H}$, et al. The Mumbai Maternal Nutrition Project (MMNP); 2018. p. 1-10. Available from: https://www.sagepub.com/ journals-permissions http://doi.org/10.1177/1933719118799202 [Last accessed on 2021 Jun 13].

16. Drooger JC, Troe JW, Borsboom GJ, Hofman A, Mackenbach JP, Moll HA, et al. Ethnic diferences in prenatal growth and the assosiation with maternal and fetal characteristics. Ultrasound Obstet Gynecol. 2005;26(2):115-22. Available from: https:// www.interscience.wiley.com http://doi.org/10.1002/uog.1962 [Last accessed on 2021 Jun 13].

17. Jacquemyn $Y$, Sys $S U$, Vedonk $P$. Fetal biometry in different ethnic group. Early Hum Dev. 2000;57(1):1-13. http://doi. org/10.1016/s0378-3782(99)00049-3 PMid:10690707

18. Al Marri HM, Ramli RM, Azman NZ, Rahman AA, Al-Yafai J, Al-Saleem A, et al. Fetal Biometry Assessment of Femur Length for Pregnant Women in Dammam, Saudi Arabia. New Jersey, United States: IEEE; 2019. http://doi.org/10.1109/ ICOM47790.2019.8952045

19. Ayad CE, Ibrahim AA, Garelnabi ME, Ahmed BH, Abdalla EA Saleem MA, et al. Assesmen of used formulae for sonographic estimation of fetal sonographic estimation of fetal weight in Sudanese population. Open J Radiol. 2016;6:113-20. Available from: http://www.scirp.org/journal/ojrad http://doi.org/10.4236/ ojrad.2016.62017 [Last accessed on 2021 Jun 13]

20. Hadlock FP, Russelli LD, Harris RB, Senung KP. Fetal Abdominal Circumference as a Predictor of Menstrual Age. United States: Radiology and Obstetrics and Gynecology, Baylor College of Medicine and Departement of Biometry, University Texas School of Public Science; 1982. p. 367-70. 